\title{
Economic and Land Use Impacts of Improving Water Use Efficiency in Irrigation in South Asia
}

\author{
Farzad Taheripour ${ }^{1 *}$, Thomas W. Hertel' ${ }^{1}$, Badri Narayanan ${ }^{2}$, Sebnem Sahin ${ }^{3}$, \\ Anil Markandya ${ }^{4}$, Bijon Kumer Mitra ${ }^{5}$
}

${ }^{1}$ Department of Agricultural Economics, Purdue University, West Lafayette, USA

${ }^{2}$ School of Environment, University of Washington, Seattle, USA

${ }^{3}$ The World Bank, Washington DC, USA

${ }^{4}$ Basque Centre for Climate Change, Spain and Bath University, Bath, UK

${ }^{5}$ Institute for Global Environmental Strategies, Hayama, Japan

Email: *tfarzad@purdue.edu

How to cite this paper: Taheripour, F., Hertel, T.W., Narayanan, B., Sahin, S., Markandya, A. and Mitra, B.K. (2016) Economic and Land Use Impacts of Improving Water Use Efficiency in Irrigation in South Asia. Journal of Environmental Protection, 7, 1571-1591.

http://dx.doi.org/10.4236/jep.2016.711130

Received: August 26, 2016

Accepted: October 25, 2016

Published: October 28, 2016

Copyright $\odot 2016$ by authors and Scientific Research Publishing Inc. This work is licensed under the Creative Commons Attribution International License (CC BY 4.0).

http://creativecommons.org/licenses/by/4.0/

(c) (i) Open Access

\begin{abstract}
This paper modifies and uses an advanced computable general equilibrium model coupled with biophysical data on land and water resources by Agro-Ecological Zone (AEZ) at the river basin level to examine the economy-wide consequences of improvements in water use efficiency (WUE) in irrigation in South Asia. This is the first time the benefits of such improvements have been evaluated in an economywide context. It shows that such improvements increase production of food items, enhance food exports, and significantly improve food security in South Asia. Improvement in water use efficiency also leads to lower food prices, provides the opportunity to extend irrigated areas, decreases demand for cropland, and enhances reforestation. Improvement in water use efficiency in irrigation also generates important net GDP gains across the South Asia region. Investments in improved WUE of up to $40 \%$ can be economically justified in Bangladesh, India, and Sri Lanka. However, in Nepal, for an improvement of more than 20\% in WUE, the economic gains are smaller than costs from the associated investments. In Pakistan and rest of South Asia, an improvement in WUE of up to $30 \%$ appears to be economically profitable.
\end{abstract}

\section{Keywords}

General Equilibrium, Water Use Efficiency, Economy Wide Impacts, Irrigation, Land Use Change, South Asia

\section{Introduction}

It is widely acknowledged that the economies of South Asia will face major water chal- 
lenges over the coming decades [1]-[3]. Population growth coupled with economic growth will significantly extend the demand for water in these economies, in particular for irrigation where water use efficiency (WUE) is very low ${ }^{1}$. Of course, with no further improvement in water use efficiency, these economies will also need considerable investment to expand their water supply to meet the growing demand for water ${ }^{2}$. However, several studies have argued that it is possible to satisfy the growing demand for water (and land as well) by improving WUE in irrigation and other uses of water (e.g. [4]-[6]). While several papers have addressed the potential for improved WUE in South Asia [7] [8] [9] [10] [11], to the best of our knowledge, no one has yet examined the extent to which WUE could affect macro-economic outcomes, production, food security, and trade in these economies.

The share of agriculture in the Gross Domestic Product (GDP) of the South Asian countries is relatively large (e.g. 16\% in Bangladesh, 19\% in India, 32\% in Nepal, $12 \%$ in Pakistan, and $21 \%$ in Sri Lanka in 2011). In addition, crop production in these countries relies heavily on irrigation. The share of irrigated cropland in total cropland was 40\% in South Asia in 2011. The corresponding figure for the rest of the world was 17\% in this year. India alone produces $18.5 \%$ of irrigated crops worldwide, while controlling $24 \%$ of the global irrigated land in 2011 . The existing literature shows that the gap between actual and potential crop yields is quite large in South Asia. For example, a recent study conducted by the World Bank [6] indicated that the attainable wheat and paddy rice yields are twice their actual yields in many of India's states. Any yield improvement could help to use water and land resources more efficiently by increasing the "crop per drop" of water. In summary, any improvement in WUE or crop yield could generate significant gains in the GDP of these countries.

Although WUE can be improved in both agricultural and non-agricultural activities, improvements in irrigation have a greater potential in this region, since irrigation is massively used in South Asia. There are two ways to increase WUE in irrigation: (a) improvements in the delivery of irrigation water to the crop, and (b) improvements in the utilization of water by the plant, once it has been delivered. Both are quantitatively important. In a comprehensive study, McKinsey \& Company found that WUE could be improved significantly in Asia [5]. Their study shows that the demand for water in India will be about 1498 billion cubic meters in 2030 and that about 756 billion cubic me-

${ }^{1}$ There are two different but related concepts that refer to efficiency of water used in irrigation. The first one refers to the ratio between water that actually transpires by crops and water withdrawal for irrigation. This is the usual definition of water use efficiency (WUE). The second concept refers to crop yields per volume of water withdrawal for irrigation. This is referred to as Water Productivity (WP). These two concepts represent two sides of the same coin. Several studies have shown that WUE is low in South Asia, regardless of the method and year of estimation. For example, Seckler et al. [13], Rohwer et al. [14], and Frenken [15] estimate the overall WUE in irrigation in South Asia to be below 40\% in many countries. For instance, according to Rohwer et al. [14] WUE in the early 2000s was 38\% in Bangladesh, India and Nepal, 29\% in Pakistan and 55\% in Sri Lanka. Several papers also have shown that WP in South Asia compared to other regions is also low (for example, see Cai and Rosegrant [16]). Note also that the concept of WUE is subject to debate [17]. A portion of water lost in irrigation systems could flow back to the river, recharge the aquifers, or be captured and reused. So the ratio of WUE may underestimate the efficiency of irrigation systems.

${ }^{2}$ Even with additional investment, it is hard to extend water supply in many regions in South Asia where water resources are already stressed due to over exploitation. 
ters of this demand can be met by saving in irrigation water at reasonable costs. In addition, in a recent policy guideline published by Ministry of Water Recourses of India [12], the Government of India has committed to the implementation of conservation policies to improve WUE across all uses $20 \%$ by 2017.

As stated above, this paper contributes to the existing literature by assessing the economy-wide implications of WUE in South Asia within an advanced computable general equilibrium (CGE) framework, linked to biophysical data on land and water resources. We organize land use by Agro-ecological zone (AEZ) in each river basin and identify water use by river basin. This allows us to examine: 1) the economy-wide consequences of improved WUE in South Asia; 2) the extent to which enhanced WUE can increase food production and improve food security in South Asia; and 3) how WUE alters demand for irrigated land and affects land use across South Asia. By employing several alternative scenarios to cover a wide range of WUE rates in irrigation under alternative assumptions on the required capital costs to improve WUE in irrigation we are able to offer insights into the relative costs and benefits of improved WUE in South Asia.

\section{Model}

The modeling framework used in this paper is an extension of the GTAP-E model [18] [19] which is a static model and allows substitution among energy inputs. It assumes energy and capital are substitutable inputs in economic activities, except for primary energy sectors such as gas, coal, and oil. In a series of modifications (including but not limited to Keeney and Hertel [20], Birur et al. [21], and Taheripour et al. [22]) land by AEZ, biofuels, and biofuels by-products were introduced in this model to make it suitable to study the economic and environmental impacts of biofuel production and policies. The new model has been labelled "GTAP-BIO" and is widely used to examine the consequences of biofuel production at the global scale (examples are: Hertel et al. [23], Tyner et al. [24], Taheripour et al. [25], and Beckman et al. [26]). More recently it has been modified to track supplies of, and demands for, land and water resources within a country at a spatial resolution of a river basin (RB) by AEZ level at the global scale and to take into account competition for water across its alternative uses [27] [28] [29]. The fundamental dataset in which the Input-Output tables of various countries are reconciled with international trade, tariff, domestic support, energy and agricultural datasets, is GTAP data Base, documented in Narayanan et al. [30]. The model developed due to this set of modifications is nicknamed GTAP-BIO- $\mathrm{W}^{3}$. This model carries all properties, characters, and validations of the GTAP standard, GTAP-E, and GTAP-BIO models and their parameters as mentioned above. It traces demand for and supply of water by country at RB-AEZ level and takes into account competition for water across agricultural and non-agricultural uses. In what follows we explain the major aspects of this model.

${ }^{3}$ Our database represents countries by river basins at the global scale. However, in this research an aggregated version of this database is used to focus on the economies of South Asia. 
Figure 1 represents the GTAP-BIO-W approach in allocating primary inputs including labor, capital, resources, land and water. In this model competition for labor, capital, and resources takes place at the national level. This means that firms compete for these primary inputs only at that level.

In Figure 1 the competition for these endowments occurs within the green box which represents a national economy including several river basins. Sectors take labor, capital, and resources from the national pool. Labor and capital are, as usual, mobile inputs. This means that these endowments move freely across uses. Following the standard GTAP model, land, water, and other resources are modeled as sluggish endowments. This means that they cannot move easily across sectors.

Competition for water takes place at the RB level. As shown Figure 1, a given national economy may have several river basins. In each river basin water has two main uses. A portion goes for irrigation and the rest goes for other purposes. As shown in Figure 1 each river basin may serve several AEZs. So AEZs within each RB compete for irrigation (see the blue box). The GTAP-BIO-W model also represents available managed

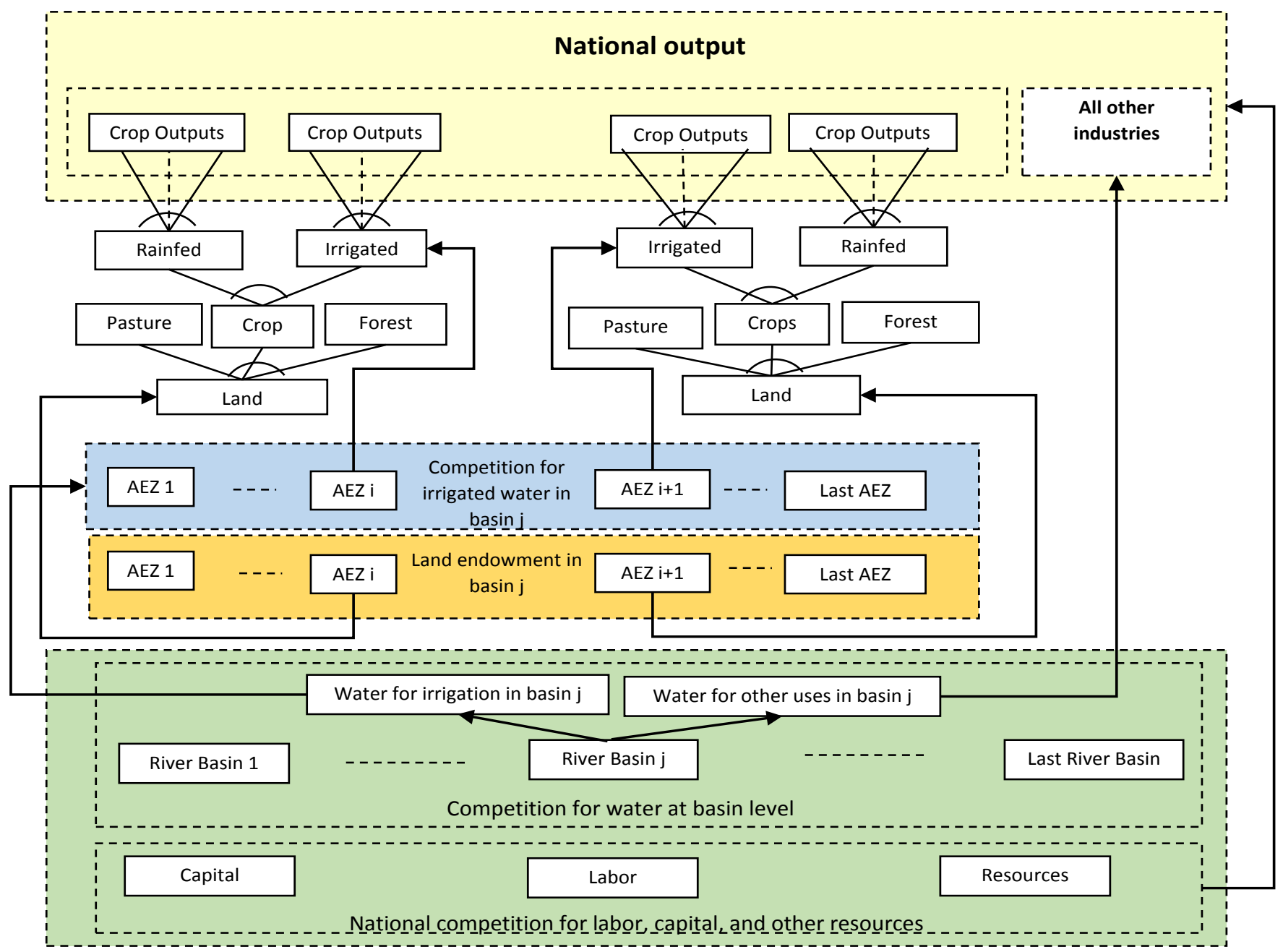

Figure 1. Structure of the GTAP-BIO-W static model. 
land at the RB-AEZ level. In each RB-AEZ the area of available managed land is divided between forest, pasture and cropland, as shown in Figure 1. Then irrigated and rainfed crops compete for cropland. Land, of course, cannot move across RB-AEZs. The irrigated crop producers compete for managed water in each RB at the AEZ level. This means that competition for water for irrigation also takes place at the spatial resolution of RB-AEZ. Finally irrigated crops compete for irrigated cropland and rained crops compete for rainfed cropland. In this model water can move from one AEZ to another one in a river basin. A constant elasticity of transformation governs the movement of water across the AEZs of a river basin.

\section{Experiments Undertaken}

Using the GTAP-BIO-W model we conducted several experiments to examine the extent to which changes in WUE in irrigation affects economies of South Asia. Given the uncertainty in the extent to which the economies of South Asia can actually improve WUE in irrigation, four different levels of efficiency gains are considered: $10 \%, 20 \%$, $30 \%$, and $40 \%$. Improvements in WUE were examined under two alternative cost assumptions. We first assumed that improvement in WUE is costless. While clearly unrealistic, this is useful in giving an upper bound on the value of the efficiency gains. Then, we developed four experiments which take into account the fact that improvements in WUE will require additional investment. There are several alternatives methods for improving WUE, including: reduction in over-irrigation, no-till farming, optimizing fertilizer application rates, using systems of rice intensification, investing in improvements to the existing systems for water collection and conveyance, alternative wet and drying practices in rice production, using micro irrigation technologies (sprinkler and drip irrigation), along with a number of other options. Some of these methods (e.g. reduction in over irrigation, no till farming, optimizing fertilizer application rates) improve WUE at no or low costs. These are often termed "no-regrets options" as they appear to be beneficial in any case. However, the extent to which these no-regrets options policies contribute to WUE is limited. To save more water in irrigation higher cost technologies such as micro irrigation, advanced rice cultivation and irrigation methods, or improvement in water infrastructure are required.

Many papers have examined the costs, returns, and rate of improvement in WUE for a range of water saving technologies at the farm level ([7] [8] [9] [10] [11]. However, limited information at the national level is available in this area. McKinsey [5] has developed a stepwise water availability supply curve for India. This supply curve covers a wide range of alternative methods which can be implemented to save consumption of water or extend its supply. It shows that water supply (including saving in consumption of water) can be expanded in India by 756 billion cubic meters with a modest investment of $\$ 5.9$ billion-less than 0.8 cents per cubic meter saved. Given that the extent to which low costs methods could reduce water consumption is limited and that the advanced irrigation and cultivation methods are expensive, this figure seems very small. According to Palanisami et al. [10], the average costs of saving in water consumption 
with sprinkler and drip irrigation systems were about 14 cents and 16 cents per cubic meter saved, respectively, for those farmers who installed these systems in 7 states of India prior to 2010. The corresponding cost in the McKinsey curve is less than 3 cents per cubic meter saved.

In a new research undertaken at the Massachusetts Institute of Technology, Winchester et al. [31] developed a set of stepwise irrigated land supply functions for major river basins across the world. These functions were introduced into a CGE model (EPPA) to examine the impact of water scarcity on food, bioenergy and deforestation at global scale. These supply functions show the costs of expansion in irrigated cropland due to water saving activities. Using the results of this research we developed a set of stepwise investment schedules which show required investment for four levels of $10 \%$, $20 \%, 30 \%$, and $40 \%$ improvement in WUE by country for South Asian economies (top panel of Table 1). For example, this table shows that on average WUE in irrigation can be improved by $10 \%$ in India at a cost of $\$ 27$ per hectare of irrigated cropland. To attain a $20 \%, 30 \%$, and $40 \%$ improvement in WUE the average investment costs grow to $\$ 63, \$ 142$, and $\$ 289$ per hectare of irrigated land. These figures show that the average investment costs grow with an increasing rate as the level of improvement in WUE expands. The higher the level of improvement in WUE the higher the average investment costs per hectare. As shown in the top panel of Table 1, the investment costs per hectare vary across regions. India and Pakistan represent the lowest and highest cost schedules, respectively. We used these cost schedules and irrigated areas of each country to evaluate the capital requirements for each level of improvement in WUE at 2011 prices (bottom panel of Table 1).

This table indicates that the capital requirement for an improvement in WUE by $10 \%$ in Bangladesh, India, Nepal, Pakistan, Sri Lanka, and rest of South Asia are about \$212 million, \$2000 million, \$49 million, \$608 million, \$36 million, \$62 million. The size of capital requirement grows as desired improvement in WUE grows in each country and it depends on the size of the irrigated agricultural land and the required water saving technology. The largest capital requirements belong to India and the smallest to Sri

Table 1. Costs of improvement in water use efficiencies in South Asia by country at 2011 prices.

\begin{tabular}{cccccccc}
\hline Description & $\begin{array}{c}\text { Level of } \\
\text { improvement } \\
\text { in WUE }\end{array}$ & Bangladesh & India & Nepal & Pakistan & Sri Lanka & $\begin{array}{c}\text { Rest of } \\
\text { South Asia }\end{array}$ \\
\hline $\begin{array}{c}\text { Average costs for } \\
\text { each level of } \\
\text { improvement }\end{array}$ & $10 \%$ & 31 & 27 & 33 & 35 & 41 & 35 \\
in WUE (\$/ha) & $30 \%$ & 16 & 63 & 78 & 83 & 96 & 83 \\
& $40 \%$ & 340 & 289 & 358 & 380 & 440 & 380 \\
$\begin{array}{c}\text { Capital requirement } \\
\text { for each level of } \\
\text { improvement in }\end{array}$ & $10 \%$ & 212 & 2000 & 49 & 608 & 36 & 63 \\
WUE (million \$) & $30 \%$ & 503 & 4735 & 116 & 1441 & 86 & 149 \\
& $40 \%$ & 2307 & 21736 & 531 & 6612 & 393 & 685 \\
\hline
\end{tabular}


Lanka at each level of WUE, since these two countries hold the largest and smallest irrigated areas in South Asia.

We create, within the CGE model, a mechanism to finance these investment costs. In this mechanism, the public sector pays for the investment costs by reducing the existing electricity subsidy rates. In South Asia, consumption of electricity is highly subsidized. For instance, the electricity subsidies paid in Bangladesh, India, Pakistan, and Sri-Lanka were about $2.63 \%, 0.32 \%, 1.31 \%$, and $0.47 \%$ of their respective total GDPs in 2011 [32]. Among all electricity users, agriculture usually pays the lowest tariff rates and receives the highest subsidy rates. The agricultural electricity tariff rates in Bangladesh, India, Nepal, Pakistan, and Sri Lanka were about 2.6 cents, 3.5 cents, 5 cents, 6.2, and 13.6 cents per kWh in 2011, respectively. The corresponding industrial tariff rates were about 5.4 cents, 11.3 cents, 9.5 cents, 10.3 cents, and 9.1 cents in 2011 [33] . We estimate that the agricultural electricity subsidy rates ${ }^{5}$ in Bangladesh, India, Nepal, Pakistan, and Sri-Lanka were about 55\%, 41\%, 29\%, 23\%, and $11 \%$ in 2011 . It is frequently argued that these subsidies encourage over consumption of electricity and water in agriculture. In our simulations it is assumed that the overall investment costs of improvement in WUE will be financed by a public loan (at a $5 \%$ annual interest rate) and the loan will be paid off in 15 years using the fiscal savings from reduced electricity subsidies paid to all electricity users ${ }^{6}$ during this time period.

The experiments introduced in this section are examined in a comparative static framework. In each experiment we impose the desired rate of improvement in WUE as an exogenous shock to the current economy. Then we compare the simulation results with the status quo conditions.

\section{Results}

\subsection{Simulation Results If Improvement in WUE Is Costless}

\subsubsection{Impacts on Food Production and Imports}

Food production goes up significantly in South Asia even with a 10 percent improvement in WUE, and it grows as efficiency improves (Table 2). With a 10 percent improvement in WUE, food production would increase annually by $\$ 739$ million (1.4\%), $\$ 7,887$ million (1.2\%), $\$ 46$ million (0.6\%), $\$ 1847$ million (1.3\%), $\$ 81$ million (0.3\%), and $\$ 214$ million (2.2\%) at 2011 constant prices in Bangladesh, India, Nepal, Pakistan, Sri Lanka, and rest of South Asia, respectively (Table 2).

With a 40 percent improvement in WUE, the corresponding figures would grow to \$2717 million (5\%), \$26,426 million (4\%), \$111 million (1.4\%), \$6,102 million (4.4\%), $\$ 212$ million (0.9\%), and $\$ 611$ million (6.3) respectively (Table 2).

Now consider the impacts of improvements in WUE on the production of individual crops (Figure 2). Bangladesh, Pakistan, and rest of South Asia experience larger ${ }^{4}$ According to Jamil [33] this reference, the electricity tariff for agriculture where higher than the tariff for industry in Sri Lanka in 2000-2011.

${ }^{5}$ The subsidy rate is defined as the ratios of tariff paid by the final user over the production and distribution costs.

${ }^{6}$ It is assumed that the life time of installed equipment is also 15 years. If the equipment last more than 15 years, then there will some gains with no corresponding costs. 
Table 2. Impacts of improvement in WUE on food production at constant 2011 prices (million $\$)$.

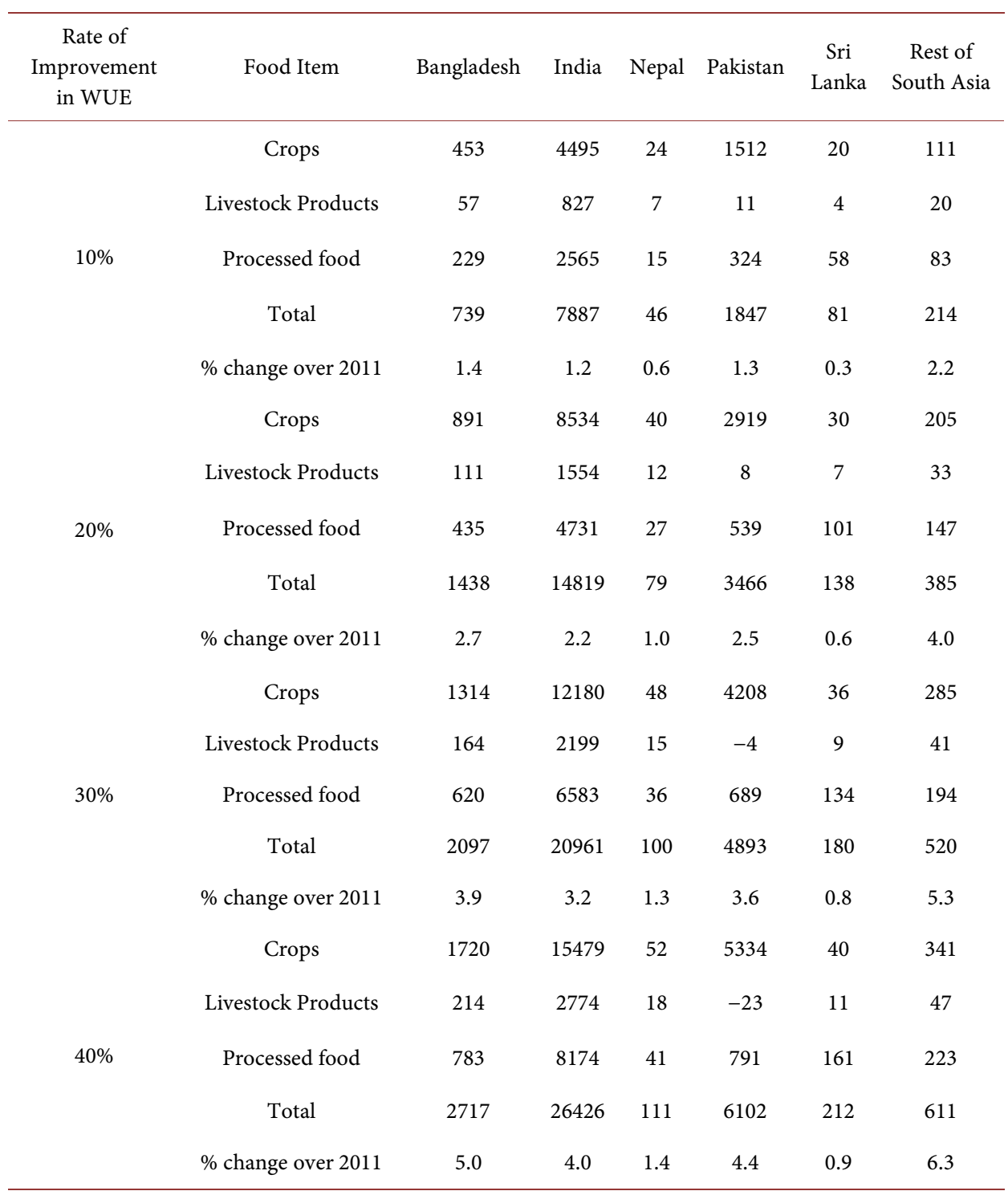
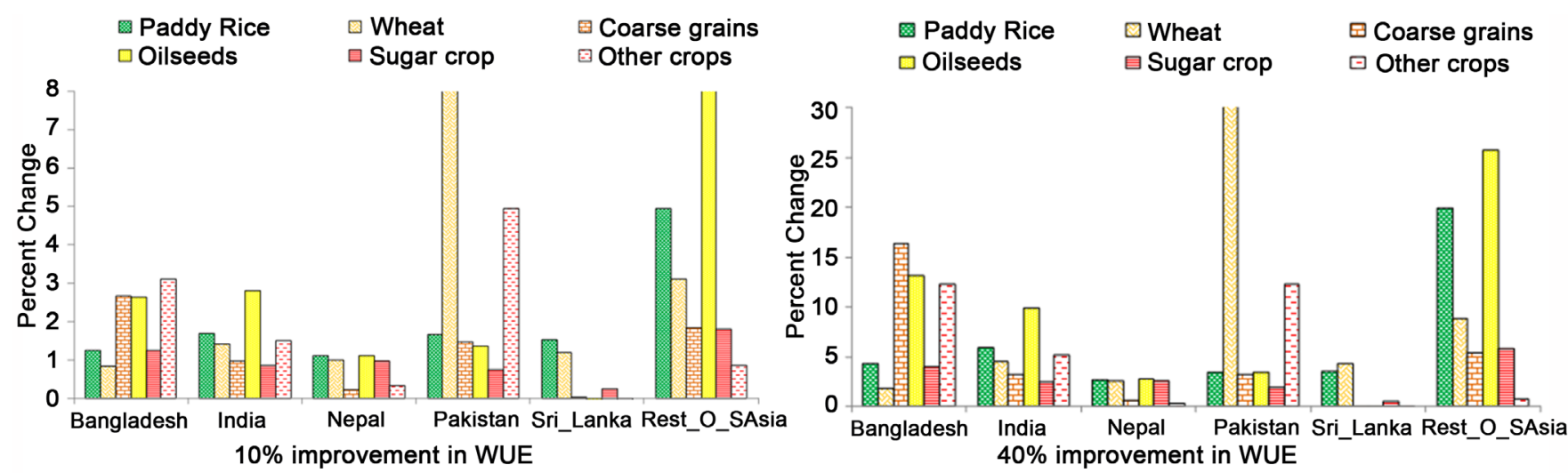

Figure 2. Impacts of improvement in water use efficiency on crop outputs in South Asia. 
percentage changes in their crop outputs compared to India, Nepal and Sri Lanka. Outputs of all crops and in particular coarse grains, oilseeds, and other crops rise in Bangladesh. In India rice and oilseeds go up more than others. In Nepal, changes in crop outputs remain small, even at $40 \%$ improvement in WUE. Outputs of wheat and other crops are most responsive in Pakistan. In Sri Lanka only outputs of rice and wheat grow due to improvement in WUE. Finally, outputs of rice, wheat and oilseeds grow in rest of South Asia as shown by Figure 2.

The gap between the irrigated and rainfed crop yields helps to explain the observed variations in the regional impacts of WUE on crop outputs. An improvement in WUE saves water on existing irrigated land and that provides an opportunity to use a portion of the saved water to convert existing rainfed cropland to irrigated cropland. In these circumstances, the gain in crop production depends on the difference between the irrigated and rainfed crop yields. If the difference is not large, the expansion in crop production will be limited. However, if the difference is large, then crop production can grow significantly. In India, for example, the difference between the rainfed and irrigated yields are not large, on average. Hence, an improvement in WUE in this country generates moderate gains in crops outputs. However, in Bangladesh, Pakistan, and rest of South Asia where irrigation contributes more to crop yields, an improvement in WUE, generates larger changes in crops outputs. Notice that in areas where the gap between the rainfed and irrigated yields are large, water requirement is also large.

Expansion in crop supply due to improvements in WUE directly enhances the food security of South Asian countries, which is assumed to be a function of total supply of food, its reliability, and its price. However, improvement in WUE indirectly advances the food security of South Asia as well. As mentioned above improvement in WUE provides an opportunity to convert rainfed cropland to irrigated cropland. Given that irrigated crops are less vulnerable to the extreme weather conditions, expansion in irrigated crops enhances food security. The extent to which improvement in WUE enhances production of irrigated crop is shown in Figure 3, which represents changes in the market share of rainfed in total production of each crop due to improvement in WUE at $10 \%$ and $40 \%$ levels. For example, a $40 \%$ improvement in WUE decreases the market share of rainfed wheat in total production of wheat by $7.8 \%, 2.7 \%, 1.5 \%, 1.7 \%$, 4\%, and 19.2\% in Bangladesh, India, Nepal, Pakistan, Sri Lanka, and rest of South Asia, respectively. The corresponding reductions for oilseeds are $8.2 \%, 14.6 \%, 6.2 \%, 23 \%, 0.01 \%$, and $14.7 \%$. One can see similar patterns for other crops as well. This line of enhancement in food security will be discussed in the next section when we analyze induced land use changes of improvement in WUE.

The expansion in food production due to improvement in WUE increases the net exports of food products (crops, livestock products, and processed food) from South Asia (Table 3). Improvement in WUE extends the net exports of food products of South Asian countries except for Sri Lanka. The net exports of food products of this country drops slightly at all levels of improvement in WUE. With a 10 percent improvement 


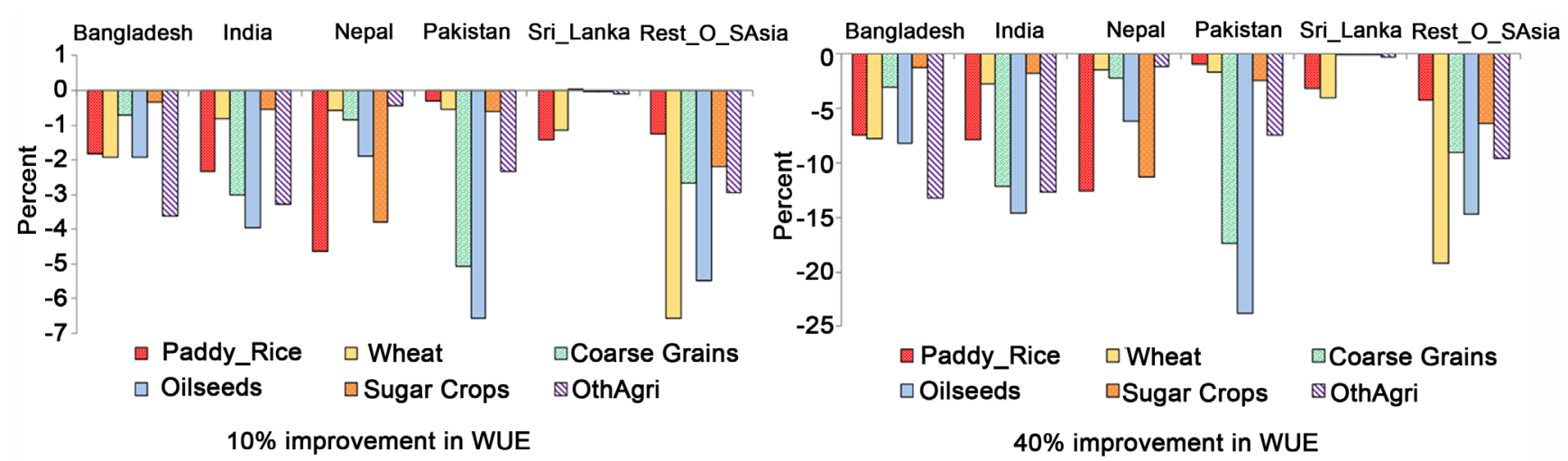

Figure 3. Reduction in the market shares of rainfed crops due to improvement in WUE.

Table 3. Impacts of improvement in WUE on net exports of food products at constant 2011 prices (million \$).

\begin{tabular}{|c|c|c|c|c|c|c|c|}
\hline $\begin{array}{c}\text { Rate of } \\
\text { Improvement } \\
\text { in WUE }\end{array}$ & Food Item & Bangladesh & India & Nepal & Pakistan & Sri Lanka & $\begin{array}{c}\text { Rest of } \\
\text { South Asia }\end{array}$ \\
\hline \multirow{4}{*}{$10 \%$} & Crops & 239 & 1144 & 9 & 1040 & -24 & 47 \\
\hline & Livestock Products & -2 & 59 & 3 & -37 & -1 & 15 \\
\hline & Processed food & 53 & 987 & 13 & -206 & 12 & 74 \\
\hline & Total & 290 & 2189 & 25 & 797 & -13 & 136 \\
\hline \multirow{4}{*}{$20 \%$} & Crops & 459 & 2179 & 14 & 1992 & -41 & 85 \\
\hline & Livestock Products & -4 & 107 & 6 & -67 & -1 & 26 \\
\hline & Processed food & 101 & 1808 & 23 & -388 & 21 & 128 \\
\hline & Total & 556 & 4094 & 43 & 1538 & -21 & 239 \\
\hline \multirow{4}{*}{$30 \%$} & Crops & 662 & 3118 & 16 & 2843 & -54 & 118 \\
\hline & Livestock Products & -6 & 147 & 7 & -91 & -1 & 34 \\
\hline & Processed food & 142 & 2500 & 29 & -544 & 29 & 166 \\
\hline & Total & 798 & 5765 & 53 & 2208 & -26 & 317 \\
\hline \multirow{4}{*}{$40 \%$} & Crops & 848 & 3974 & 17 & 3567 & -64 & 140 \\
\hline & Livestock Products & -8 & 181 & 8 & -110 & -1 & 39 \\
\hline & Processed food & 176 & 3087 & 34 & -672 & 36 & 189 \\
\hline & Total & 1017 & 7242 & 59 & 2784 & -30 & 368 \\
\hline
\end{tabular}

in WUE, the net exports of food products of Bangladesh, India, Nepal, Pakistan, and the rest of South Asia will increase by $\$ 290$ million, \$2189 million, \$25 million, \$797 million, and $\$ 136$ million at 2011 constant prices, respectively. The corresponding figures with a 40 percent improvement in WUE will be about $\$ 1017$ million, $\$ 7242$ million, \$59 million, \$2784 million, and \$368 million, respectively. These figures show that India, Pakistan, and Bangladesh could gain significantly in trade of food products, if 
they use their water resources more efficiently. Of course expansion in food production and exports could positively affect rural income and living conditions in these regions.

\subsubsection{Price Impacts}

Improvement in WUE reduces the prices of food products in South Asia considerably. However, the price impact varies by region and food product ${ }^{7}$. For example, other factors being the same, a 40 percent improvement in WUE could reduce the price index of crops by $18.9 \%$ in Bangladesh, $12.4 \%$ in India, $11.1 \%$ in Nepal, $16.6 \%$ in Pakistan, $4.5 \%$ in Sri Lanka, and $17.3 \%$ in rest of South Asia (Figure 4). The rate of reduction in the price index of livestock products is smaller than the rate reduction in the crop price index in each region. With a $40 \%$ improvement in WUE the price index of livestock products drops by $11.4 \%, 5 \%, 7.7 \%, 1 \%$ and $8 \%$ in Bangladesh, India, Nepal, Sri Lanka, and Rest of South Asia, respectively. Unlike these countries, in Pakistan the price index of livestock goes up slightly by $2.3 \%$. Improvement in WUE in irrigation encourages farmers to convert some pastureland to crop production in Pakistan and that negatively affect output of livestock industries, which leads to an increase in the price of livestock products. Finally, with $40 \%$ improvement in WUE the price index of processed food decreases by $5.2 \%, 6.1 \%, 10.4 \%, 2.9 \%$, and $12 \%$ in Bangladesh, India, Nepal, Sri Lanka, and Rest of South Asia, respectively. The price index of processed food goes up slightly by $1.6 \%$ in Pakistan.

In conclusion, the positive impacts of improvements in WUE on food production plus its potential to lower food prices jointly contributed to improve food security in South Asia.

\subsubsection{Land Use Impacts}

As mentioned, improvement in WUE in irrigation reduces the rainfed harvested areas and increases irrigated areas. For example, a 10 percent improvement in WUE increases the areas of irrigated cropland by $3.9 \%$ (or 268 thousand hectares), $7.3 \%$ (or 5503 thousand hectares), $5.9 \%$ (or 87 thousand hectares), 3.1\% (or 544 thousand hectares), 2.3\% (or 20 thousand hectares), and 7\% (or 126 thousand hectares) in Bangladesh, India,
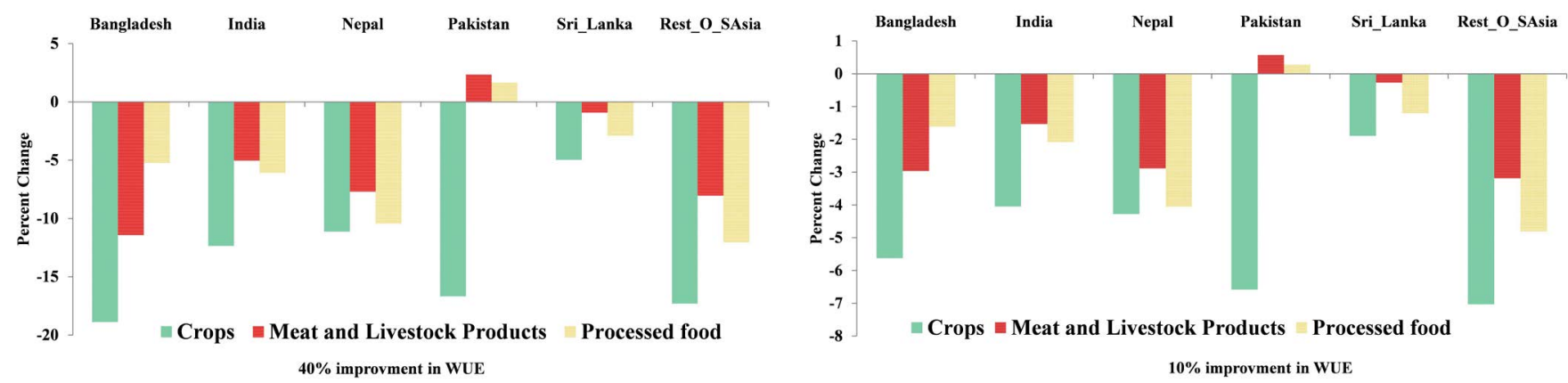

Figure 4. Impacts of improvement in water use efficiency on prices of food items in South Asia.

${ }^{7}$ The price index of primary factors is the numeraire in each region. Therefore all piece changes are relative to this numeraire. 
Nepal, Pakistan, Sri Lanka, and rest of South Asia (Table 4). The corresponding figures for $40 \%$ improvement in WUE are $16 \%$ (or 1086 thousand hectares), $28.5 \%$ (or 21,444 thousand hectares), $14.2 \%$ (or 210 thousand hectares), $12 \%$ (or 2085 thousand hectares), $5.1 \%$ (or 46 thousand hectares), and $24 \%$ (or 435 thousand hectares). These large expansions in irrigated areas could meaningfully improve the food security of South Asia against climate change.

Since irrigated areas are usually more productive than their rainfed counterpart, an improvement in WUE reduces demand for cropland and that generates some incentives for reforestation (expansions in forest and natural pasture land) across South Asia except for Pakistan (Table 5). For example, a 40\% increase in WUE reduces demand

Table 4. Changes in irrigated and rainfed harvested areas due to improvement in WUE (1000 hectares).

\begin{tabular}{|c|c|c|c|c|c|c|c|}
\hline $\begin{array}{c}\text { Rate of } \\
\text { Improvement } \\
\text { in WUE }\end{array}$ & Irrigation Type & Bangladesh & India & Nepal & Pakistan & $\begin{array}{c}\text { Sri } \\
\text { Lanka }\end{array}$ & $\begin{array}{c}\text { Rest of } \\
\text { South Asia }\end{array}$ \\
\hline \multirow{3}{*}{$10 \%$} & Irrigated area & 267.6 & 5502.7 & 87.2 & 544.0 & 20.3 & 125.7 \\
\hline & Rainfed area & -326.2 & -6193.1 & -92.0 & -556.0 & -20.7 & -138.0 \\
\hline & Total & -58.7 & -690.4 & -4.8 & -11.9 & -0.4 & -12.3 \\
\hline \multirow{3}{*}{$20 \%$} & Irrigated area & 533.2 & 11030.8 & 163.8 & 1083.3 & 32.8 & 250.1 \\
\hline & Rainfed area & -651.9 & -12374.3 & -171.5 & -1084.3 & -33.6 & -270.9 \\
\hline & Total & -118.7 & -1343.5 & -7.7 & -1.1 & -0.8 & -20.8 \\
\hline \multirow{3}{*}{$30 \%$} & Irrigated area & 800.7 & 16363.4 & 203.9 & 1608.6 & 40.7 & 364.0 \\
\hline & Rainfed area & -981.1 & -18325.0 & -213.5 & -1576.4 & -41.8 & -389.2 \\
\hline & Total & -180.4 & -1961.6 & -9.6 & 32.1 & -1.1 & -25.2 \\
\hline \multirow{3}{*}{$40 \%$} & Irrigated area & 1085.8 & 21443.5 & 210.2 & 2084.7 & 45.9 & 434.7 \\
\hline & Rainfed area & -1330.0 & -23988.8 & -221.6 & -1990.1 & -47.2 & -461.5 \\
\hline & Total & -244.2 & -2545.3 & -11.4 & 94.6 & -1.3 & -26.8 \\
\hline
\end{tabular}

Table 5. Changes in land cover due to improvement in WUE (1000 hectares).

\begin{tabular}{cccccccc}
\hline $\begin{array}{c}\text { Rate of } \\
\text { Improvement } \\
\text { in WUE }\end{array}$ & Land Type & Bangladesh & India & Nepal & Pakistan & Sri Lanka & $\begin{array}{c}\text { Rest of } \\
\text { South Asia }\end{array}$ \\
\hline \multirow{2}{*}{$10 \%$} & Forest & 43.0 & 332.3 & 2.1 & -0.2 & -0.2 & 0.0 \\
& Cropland & -58.7 & -690.4 & -4.8 & -11.9 & -0.4 & -12.3 \\
& Pasture & 15.6 & 358.1 & 2.7 & 12.1 & 0.7 & 12.3 \\
\multirow{2}{*}{$20 \%$} & Forest & 87.0 & 647.9 & 3.6 & -0.3 & -0.4 & 0.0 \\
& Cropland & -118.7 & -1343.5 & -7.7 & -1.1 & -0.8 & -20.8 \\
& Pasture & 31.7 & 695.7 & 4.2 & 1.4 & 1.2 & 20.8 \\
$30 \%$ & Forest & 132.2 & 947.3 & 4.6 & -0.1 & -0.6 & 0.0 \\
& Cropland & -180.4 & -1961.6 & -9.6 & 32.2 & -1.1 & -25.2 \\
& Pasture & 48.2 & 1014.3 & 5.0 & -32.0 & 1.6 & 25.2 \\
& Forest & 267.6 & 5502.7 & 87.2 & 544.0 & 20.3 & 125.7 \\
& Cropland & -326.2 & -6193.1 & -92.0 & -556.0 & -20.7 & -138.0 \\
& Pasture & -58.7 & -690.4 & -4.8 & -11.9 & -0.4 & -12.3 \\
\hline
\end{tabular}


for cropland by $2.5 \%$ (or 244 thousand hectares), $1.5 \%$ (or 2545 thousand hectares), $0.4 \%$ (or 11 thousand hectares), $0.1 \%$ (or 1.3 thousand hectares), and $0.3 \%$ (or 27 thousand hectares) in Bangladesh, India, Nepal, Sri Lanka, and rest of South Asia. In Pakistan at this level of improvement in WUE harvested area of irrigated land extends more than the reduction in rainfed areas and therefore total harvested area increases by $0.4 \%$ (or 95 thousand hectares) and therefore we observe some land conversion form forest and pasture to cropland. Therefore, in general, an improvement in WUE generates reforestation in South Asia as well.

Land and water endowments in India, unlike other countries in South Asia, are scattered across many river basins and different agro ecological zones representing different climate conditions and length of growing periods. Since an improvement in WUE could generate different land use patterns across the country, here we study the land use impacts of improved WUE in India by river basin and AEZ, limiting analyses to the case of 20 percent improvement in WUE. The left panel of Figure 5 shows changes in cropland, forest, and pastureland areas by river basin. This figure indicates that with a 20 percent improvement in WUE, the area of cropland shrinks across all river basins, with major reductions in Ganges (by 349,000 hectares), Krishna (142,000 hectares), Brahmari (141,300 hectares), Indus (137,000 hectares), and Mahi-Tahi $(125,000$ hectares). In return, the areas of forest and pastureland grow across all river basins.

The right panel of Figure 5 shows changes in cropland, forest, and pastureland areas by AEZ. This figure shows that, with a 20 percent improvement in WUE, areas of cropland in India shrink across several AEZs, with major reductions in AEZ3 (by 598,000 hectares), AEZ4 (192,000 hectares), AEZ2 (138,800 hectares), AEZ8 (115,000 hectares), and AEZ9 (111,000 hectares). Again, in return the areas of forest and pastureland grow across these AEZs.

The left panel of Figure 6 represents changes in the mix of irrigated and rainfed croplands by river basin with a 20 percent improvement in WUE. Irrigated area grows most in the Ganges (by 4.2 million hectares), Indus ( 2 million hectares), Krishna (1.2 million hectares), and Godavari (1 million hectares) river basins. Finally, the right panel of Figure 6 shows changes in the mix of irrigated and rain-fed croplands by AEZ with a
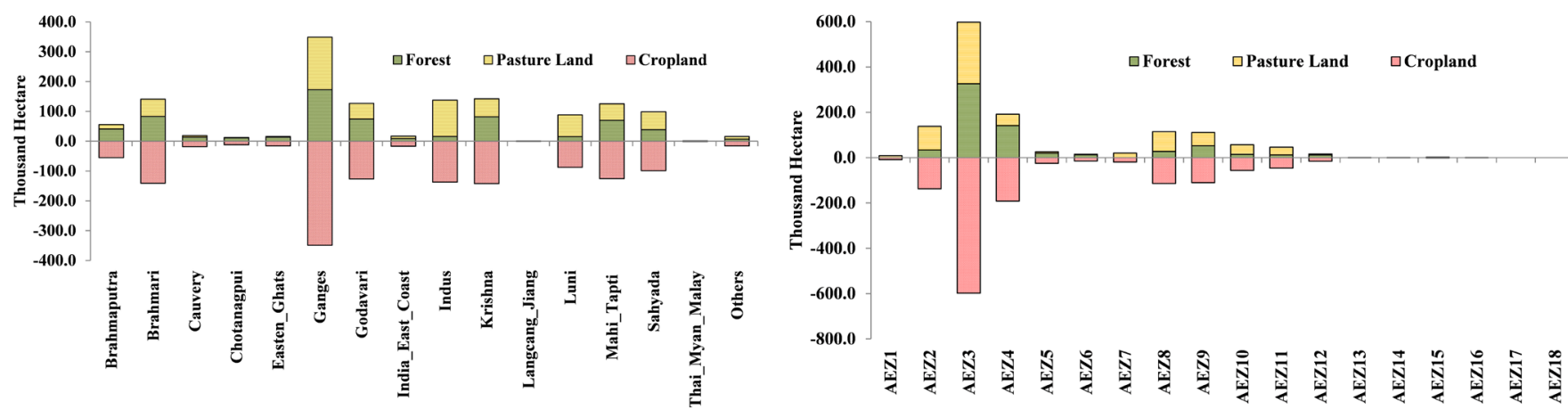

Figure 5. Land use changes in India by river basin (left panel) and by AEZ (right panel) due to $20 \%$ improvement in water use efficiency. 


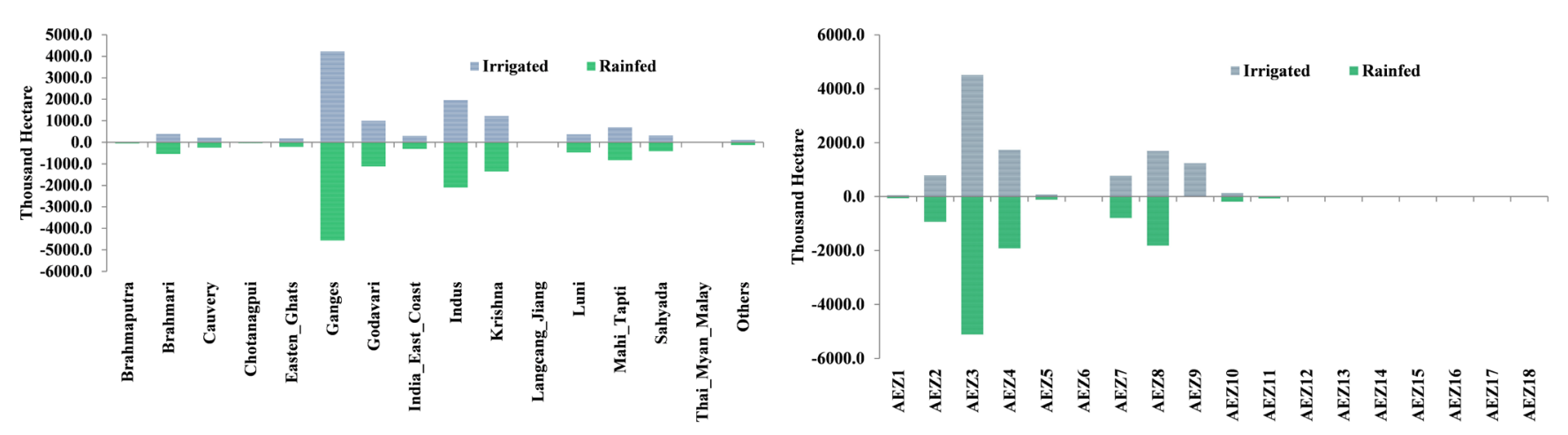

Figure 6. Changes in rainfed and irrigated cropland in India by river basin (left panel) and by AEZ (right panel) due to $20 \%$ improvement in water use efficiency.

20 percent improvement in WUE. As shown in this figure, irrigated area grows largely in AEZ3 (5.1 million hectares), AEZ4 (1.9 million hectares), AEZ8 (1.8 million hectares), and AEZ9 (1.4 million hectares).

\subsubsection{Impacts on Outputs of Non-Agricultural Sectors}

Improvements in WUE could affect outputs of non-agricultural activities through two main channels. First, as discussed, it extends agricultural activities and that could generate indirect demand for other goods and services through the forward and backward linkages between agricultural and non-agricultural actives. Second, a portion of water saved by improvements in WUE could move to non-agricultural activities and that helps these sectors to grow as well. For example, a $40 \%$ improvement in water use efficiency increases the share of non-agricultural activities in water withdrawal of: Bangladesh from $15.1 \%$ to $15.8 \%$; India from $16.8 \%$ to $19 \%$; Nepal from $3.3 \%$ to $4.5 \%$; Pakis$\tan$ from $8.8 \%$ to $9 \%$; Sri Lanka from $48.7 \%$ to $59.2 \%$; and rest of South Asia from $4 \%$ to $5 \%$. For this level of improvement in WUE the overall output of non-agricultural sectors changes by $1.8 \%, 1.4 \%, 0.9 \%,-0.2 \%, 0.7 \%$, and $0.2 \%$. These figures indicate that, except for Pakistan, an improvement in WUE increases the share of non-agricultural activities in water withdrawal and that helps these sectors to grow in South Asia.

\subsubsection{Economy-Wide Impacts}

WUE improvements also positively affect the real GDP of South Asian countries and the impact grows with the rate of the WUE improvement (Figure 7). For example, a 10 percent improvement in WUE increases the real GDP of Bangladesh, India, Nepal, Pakistan, Sri Lanka, and rest of South Asia by 1.1 percent, 0.5 percent, 0.2 percent, 0.6 percent, 0.2 percent, and 0.5 , respectively. The corresponding annual monetary value of these increases at 2011 constant prices are $\$ 1216$ million for Bangladesh, $\$ 8696$ million India, \$34 million for Nepal, \$1160 million for Pakistan, \$146 million for Sri Lan$\mathrm{ka}$, and $\$ 100$ million for rest of South Asia (Figure 7). With a 40 percent improvement in WUE, GDP grows by 3.8 percent, 1.5 percent, 0.5 percent, 1.7 percent, 0.7 percent, and 1.2 percent in Bangladesh, India, Nepal, Pakistan, Sri Lanka, and the rest of South Asia, respectively. The corresponding annual monetary gains of these increases at 2011 constant prices are $\$ 4178$ million for Bangladesh, \$27,715 million India, \$87 million for 

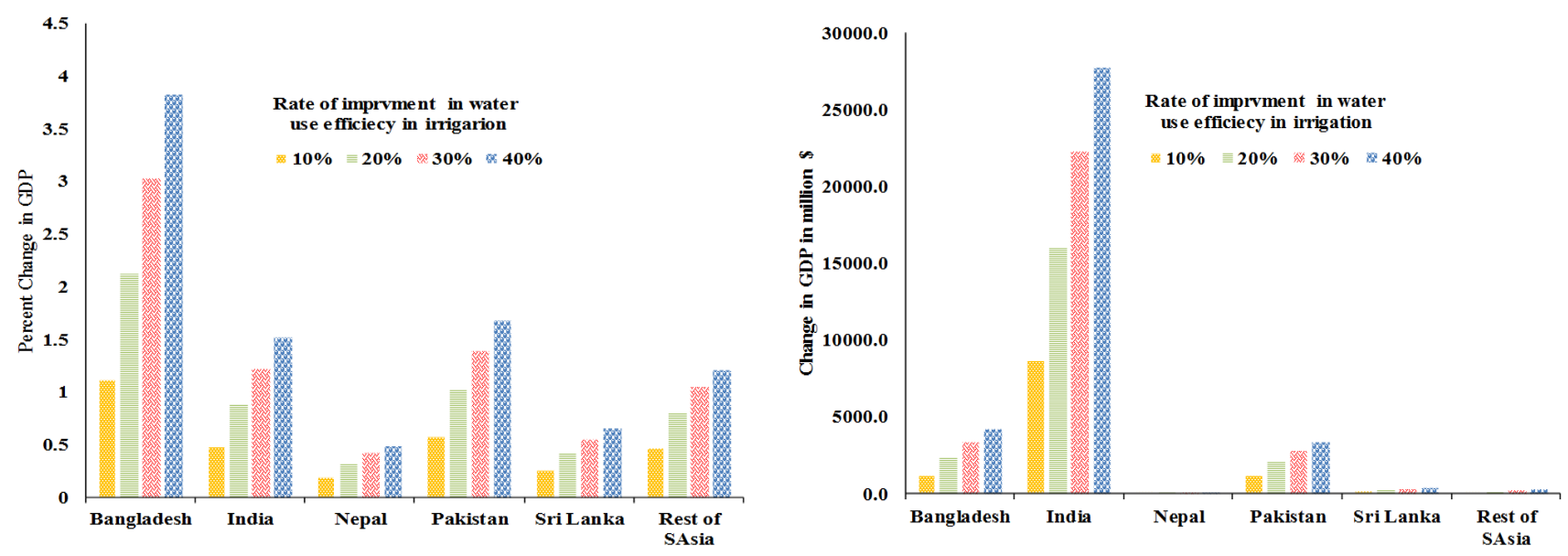

Figure 7. Percent changes in GDP (left panel) and their monetary values at 2011 constant prices (right panel) due to improvement in water use efficiency in irrigation in South Asia: Improvement in water use efficiency is costless.

Nepal, \$3357 million for Pakistan, \$380 million for Sri Lanka, and \$260 million for rest of South Asia.

An improvement in WUE in irrigation enhances GDP through several channels. First, it extends crop production, which boosts agricultural output (including livestock and forestry). Since the share of agriculture in GDP is relatively high in South Asia, this significantly increases GDP through the backward linkages among the agricultural and non-agricultural activates. As mentioned before, improvement in WUE releases some water and that allows non-agricultural sectors to grow as well. This enhances employment in South Asia, where the rate of unemployment is usually high.

It is important to note that our static simulations show that GDP grows with a decreasing margin as the level of improvement in WUE increases (Figure 8). The decreasing rate of marginal contribution of improvement in WUE matches with the economic principle of decreasing marginal product of an increasing input in a static framework. In long run when economies of South Asia grow over time any additional drop of saved water could generate growing marginal outputs when water scarcity hit these economies.

\subsection{Simulation Results When Improvement in WUE Needs Additional Investment}

\subsubsection{Impacts on Outputs, Net Exports, and Price of Food Products and Land Use Implications}

The agricultural impacts of improved WUE in the presence of additional investment charges are only slightly different from the costless cases, regardless of the level improvement in WUE. Two factors explain this observation. First, the share of electricity in the cost structures of irrigated crops in South Asia is small. Second, the public sector pays the costs of improvement in WUE with a uniform reduction in electricity subsidies across all users. So farmers only pay a small portion of the costs of improvements in WUE. Since the new results are not very different form the corresponding results of the costless cases, we do not present them in here. 


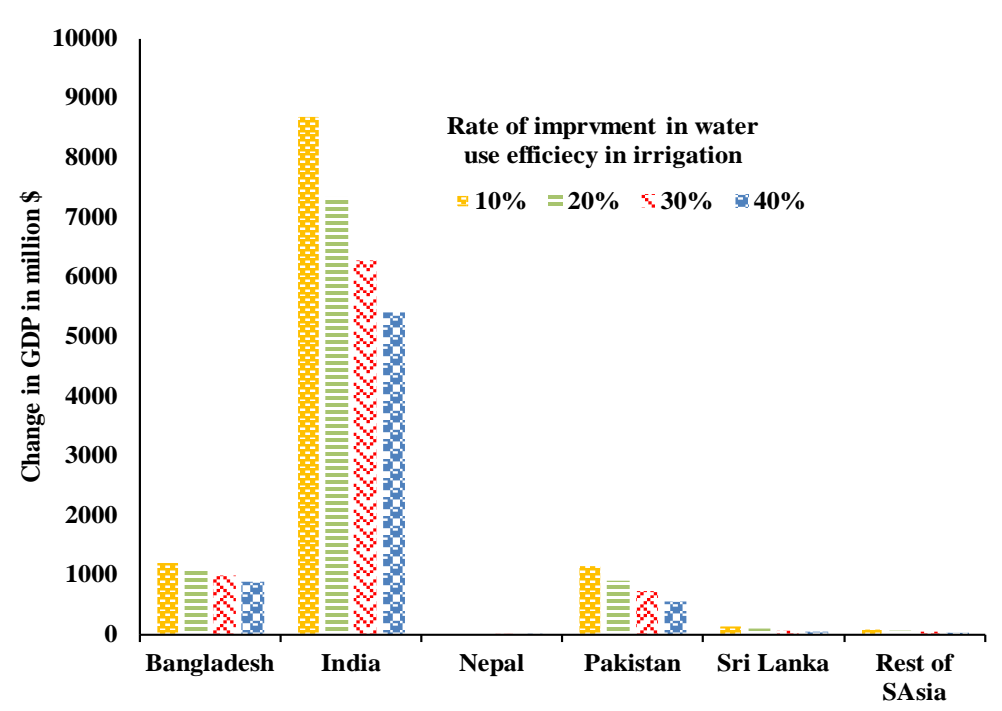

Figure 8. Marginal impacts of different levels of improvement in water use efficiency on GDP of South Asian economies: Improvement in water use efficiency is costless.

\subsubsection{Impacts on Production and Price of Electricity}

Since electricity subsidies are reduced to finance the improvements in WUE, this policy affects the production and price of electricity across South Asia. To examine these impacts, the changes in the production and price of electricity are compared for a $40 \%$ improvement in WUE under the two cases of with and without investment costs. With no investment costs for improvement in WUE, the production of electricity changes by $-1 \%, 2.6 \%, 0.5 \%, 2.6 \%, 1 \%$, and $1.5 \%$ in Bangladesh, India, Nepal, Pakistan, Sri Lanka, and rest of South Asia, respectively. The corresponding changes for the case with investment costs are $-2.6 \%, 1.5 \%,-0.5 \%, 0.5 \%, 0.1 \%$, and $-1.5 \%$. These figures show that production of electricity drops in the second case by $1 \%$ to $2 \%$ in the main countries of the region, when electricity subsidies are reduced to finance the investment costs of improvement in WUE. The reduction in electricity subsidy increases the consumer price of electricity as well. With no investment costs for improvement in WUE, consumer price of electricity changes by $5.9 \%, 0.7 \%,-1.2 \% 4.4 \%, 0.4 \%$, and $-0.9 \%$ in Bangladesh, India, Nepal, Pakistan, Sri Lanka, and rest of South Asia, respectively. The corresponding changes for the case of with investment costs are $11.8 \%, 5.3 \%, 6.7 \% 11.7 \%, 3.5 \%$, and $25 \%$. These figures are significantly higher than their corresponding figure for the costless case.

\subsubsection{Economy-Wide Impacts}

The economy-wide gains of improvement in WUE (measured in terms of changes in real GDP) decreases when we take into account costs of improvement in WUE. For example, as mentioned before a 10 percent improvement in WUE increases real GDP of Bangladesh, India, Nepal, Pakistan, Sri Lanka, and rest of South Asia respectively by 1216 million, \$8696 million, \$34 million, \$1160 million, \$146 million, and \$100 million at 2011 constant prices when we assumed improvement in WUE is costless. The corresponding figure drops to 1146 million, $\$ 8,175$ million, $\$ 29$ million, \$986 million, \$138 
million, and $\$ 90$ million when we take into account costs of improvement in WUE (Figure 9).

As was observed in the costless cases, real GDP grows with a decreasing margin as we move towards the higher levels of improvement in WUE. When we take into account the investment costs, in some countries the marginal contributions of improvement in WUE become negative at higher levels of improvement in WUE. For example, consider the case of Pakistan where the first 10\% improvement in WUE increases GDP by $\$ 1,160$ million and the last $10 \%$ (from $30 \%$ to $40 \%$ ) increases GDP by $\$ 562$ million when we assumed improvement in WUE is costless. The corresponding figures are about 986 million and $-\$ 447$ million when we take into account the investment costs (Table 6). This indicates that the gains of improving WUE from $30 \%$ to $40 \%$ do not cover the costs of this improvement. Three factors contribute to this observation. First as mentioned before, the marginal productivity of water is decreasing as its application rate rises. Second, the marginal costs of improvement in WUE grow as we move towards the higher levels of WUE. Third, the efficiency gains from reducing electricity subsidies disappears as the cuts increase-eventually turning into losses as subsidies become taxes. Table 6 indicates that the marginal impact of improvement in WUE on GDP becomes negative at higher levels of improvement in WUE in Nepal, and rest of South Asia as well.

Table 6. Marginal impact of each level of improvement in water use efficiency on GDP at 2011 constant prices with and without investment costs (million \$).

\begin{tabular}{ccccccccc}
\hline Cost assumption & \multicolumn{3}{c}{$\begin{array}{c}\text { If improvement in water } \\
\text { use efficiency is costless }\end{array}$} & \multicolumn{2}{c}{$\begin{array}{c}\text { Improvement in water use efficiency } \\
\text { needs additional investment costs }\end{array}$} \\
$\begin{array}{c}\text { Rate of } \\
\text { improvement in WUE }\end{array}$ & $10 \%$ & $20 \%$ & $30 \%$ & $40 \%$ & $10 \%$ & $20 \%$ & $30 \%$ & $40 \%$ \\
Bangladesh & 1216 & 1098 & 986 & 878 & 1146 & 1013 & 835 & 615 \\
India & 8696 & 7335 & 6275 & 5409 & 8175 & 6646 & 4873 & 2845 \\
Nepal & 34 & 24 & 17 & 11 & 29 & 17 & -2 & -27 \\
Pakistan & 1160 & 910 & 725 & 562 & 986 & 665 & 187 & -447 \\
Sri Lanka & 146 & 101 & 75 & 58 & 138 & 91 & 51 & 14 \\
Rest of South Asia & 100 & 74 & 53 & 34 & 90 & 60 & 22
\end{tabular}
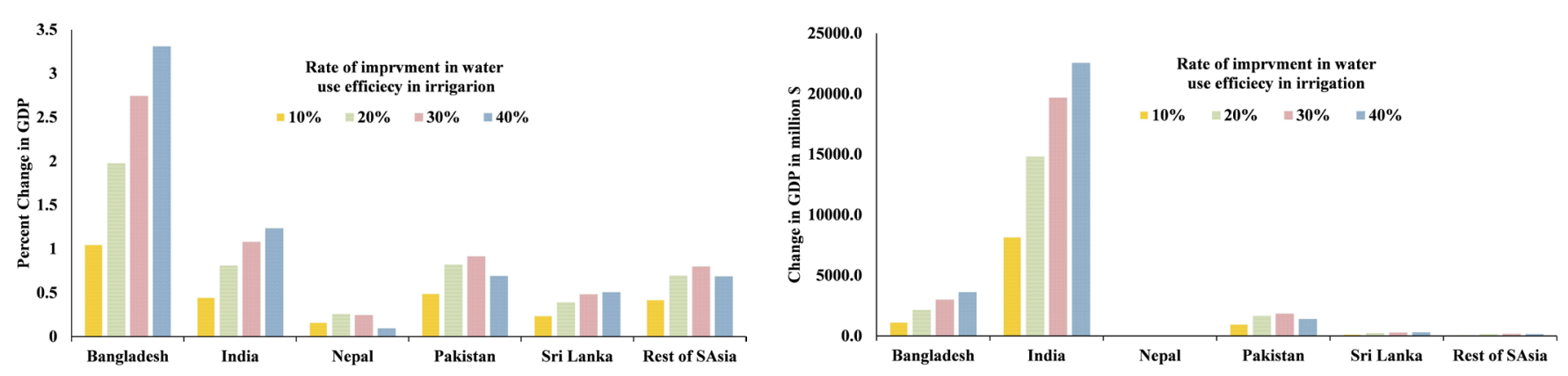

Figure 9. Percent changes in GDP (left panel) and their monetary values at 2011 constant prices (right panel) due to improvement in water use efficiency in irrigation in South Asia: Improvement in water use efficiency needs additional investment costs. 
In conclusion, Table 6 shows that improvement in WUE up to $40 \%$, financed by a reduction in electricity subsidy, can be economically justified in Bangladesh, India, and Sri Lanka. In Nepal, after 20\% improvement in WUE, the economic gains are smaller than costs. In Pakistan and rest of South Asia, an improvement in WUE over 30\% may not be economically profitable.

Finally, it is important to note that the impacts of improvements in WUE on GDP could be different from its welfare impacts due to differing impacts on aggregate consumption. Our simulation results show that the welfare impacts are in general different from the GDP impacts. For instance, a 40\% improvement in WUE increases the real GDP of Bangladesh, India, Nepal, Pakistan, Sri Lanka, and Rest of South Asia by $\$ 3610$ million, \$22,539 million, \$17 million, \$1392 million, \$295 million, and \$148 million at 2011 constant prices, respectively. The corresponding welfare impacts for this simulation are $\$ 4381$ million, $\$ 19,065$ million, $-\$ 83$ million, $\$ 3130$ million, $\$ 402$ million, and $\$ 45$ million. Hence, from the consumers' points of view the monetary value of improvements in WUE is higher than the gains in GDP in Bangladesh, Pakistan, and Sri Lanka and the reverse is true in India, Nepal, and Rest of South Asia.

\section{Conclusions}

Using an advanced computable general equilibrium model (GTAP-BIO-W), this paper shows that improvements in WUE in irrigation increase production of food items in South Asia, significantly. In addition, it has demonstrated the following beneficial impacts: a) an increase in the production of non-agricultural sectors; b) significant rises in the net food exports of South Asian economies, with an overall improvement in their trade balances; c) lower food prices, which provide the opportunity to extend irrigated areas across South Asia and lead to reforestation and more security in food production; d) notable GDP gains across south Asia.

An improvement in WUE up to $40 \%$ can be economically justified in Bangladesh, India, and Sri Lanka. In Nepal, after 20\% improvement in WUE, the economic gains are smaller than costs. In Pakistan and rest of South Asia, an improvement in WUE over $30 \%$ may not be economically profitable.

Policymakers dealing with the agricultural sector and irrigation are well aware of the benefits of improvements in WUE to that sector. What they have thus far lacked are estimates of the broader benefits to the economy as a whole from such WUE improvements. This paper provides them with estimates of these benefits. Second, there has always been the question of how to finance the improvements, given the limited public resources available. Again, this paper has shown that it is possible to finance such a program through reductions in electricity subsidies, in such a way that the net benefits from some levels of investment are positive.

Further work is needed to evaluate the options that have been presented here in more detail. In particular, it is important to better understand the distributional implications of such a financing program and consider measures to address adverse effects on low income rural households. 


\section{Acknowledgements}

We thank the seminar participants at various meetings and conferences including the World Bank, Annual Conference of Global Economic Analysis in Melbourne and Washington DC, Annual Agricultural and Applied Economic Association meeting in Boston, and the anonymous referees for their feedback on earlier drafts. We also thank Vivek Prasad for his professional contributions to this research. This paper solely reflects personal ideas of the authors and does not present the official views of their affiliated organizations.

\section{References}

[1] UNESCO (2012) Managing Water under Uncertainty and Risk. The United Nations World Water Development Report.

[2] Rosegrant, M.W., Ringler, C., Zhu, T., Tokgoz, S. and Bhandary, P. (2013) Water and Food in the Bioeconomy: Challenges and Opportunities for Development. Agricultural Economics, 44, 139-150. http://dx.doi.org/10.1111/agec.12058

[3] Rodriguez, D.J., et al. (2013) Thirsty Energy: Water Partnership Program. World Bank, Washington DC.

[4] Molden, D. (1997) Accounting for Water Use and Productivity. International Irrigation Management Institute. https://ideas.repec.org/b/ags/iwmibo/113623.html

[5] McKinsey (2009) Charting Our Water Future: Economic Frameworks to Inform DecisionMaking. McKinsey \& Company, New York.

[6] World Bank (2014) Republic of India: Accelerating Agricultural Productivity Growth. Report No. 88093-IN.

http://www.indiaenvironmentportal.org.in/files/file/Accelerating\%20Agricultural\%20Produ ctivity\%20Growth.pdf

[7] Hasanain, A., Ahmad, S., Mehmood, Z. Majeed, S. and Zinabou, G. (2012) Irrigation and Water Use Efficiency in South Asia. Research Paper 9, Global Development Network, New Delhi.

http://www.alihasanain.com/uploads/3/7/8/7/37876581/irrigation-and-water-use-efficiency 3.pdf

[8] Singh, R., Kundu, D. and Bandyopadhyay, K. (2010) Enhancing Agricultural Productivity through Enhanced Water Use Efficiency. Journal of Agricultural Physics, 10, 1-15.

[9] Radha, R. Reddy, K., Rao, G., Chandraand, S. and Babu, G. (2009) Water-Saving Rice Production Technologies in Krishna Western Delta Command of Andhra Pradesh-An Economic Analysis. Agricultural Economics Research Review, 22, 397-400.

[10] Palanisami, K., Mohan, K., Kakumanu, K.R. and Raman, S. (2011) Spread and Economics of Micro-Irrigation in India: Evidence from Nine States. Economic \& Political Weekly, 46, 81-86.

[11] Wallace, J. (2000) Increasing Agricultural Water Use Efficiency to Meet Future Food Production. Agriculture, Ecosystems and Environment, 82, 105-119. http://dx.doi.org/10.1016/S0167-8809(00)00220-6

[12] Ministry of Water Resources of India (2014) Guidelines for Improving Water Use Efficiency in Irrigation, Domestic \& Industrial Sectors. Performance Overview \& Management Improvement Organization.

http://wrmin.nic.in/writereaddata/Guidelines_for_improving_water_use_efficiency.pdf 
[13] Seckler, D., Amarasinghe, U., Molden, D., de Silva, R. and Barker, R. (1998) World Water Demand and Supply 1990 to 2025: Scenarios and Issues. International Irrigation Management Institute, Colombo.

http://www.iwmi.cgiar.org/Publications/IWMI_Research_Reports/PDF/PUB019/REPORT1 9.PDF

[14] Rohwer, J., Gerten, D. and Lucht, W. (2007) Development of Functional Irrigation Types for Improved Global Crop Modeling. Potsdam Institute for Climate Impact Research, Postdam.

[15] Frenken, K. (2011) Irrigation Water Requirement and Water Withdrawal by Country. AQUASTAT Survey, Food and Agriculture Organization of the United Nation, Rome.

[16] Cai, X. and Rosegrant, M. (2003) World Water Productivity: Current Situation and Future Options. In: Kijne, J., Barker, R. and Molden, D., Eds., Water Productivity in Agriculture: Limits and Opportunities for Improvement, CABI International, Cambridge, 163-178. http://dx.doi.org/10.1079/9780851996691.0163

[17] Frenken, K. and Gillet, V. (2012) Irrigation Water Requirement and Water Withdrawal by Country. AQUASTAT Report, Food and Agriculture Organization of the United Nation, Rome. http://www.fao.org/3/a-bc824e.pdf

[18] Burniaux, J. and Truong, T. (2002) GTAP-E: An Energy-Environmental Version of the GTAP Model. GTAP Technical Paper No. 16, Center for Global Trade Analysis, Purdue University, West Lafayette. https://www.gtap.agecon.purdue.edu/resources/res_display.asp?RecordID=923

[19] Mcdougall, R. and Golub, A. (2007) GTAP-E: A Revised Energy-Environmental Version of the GTAP Model. GTAP Research Memorandum No. 15, Center for Global Trade Analysis, Purdue University, West Lafayette. https://www.gtap.agecon.purdue.edu/resources/res_display.asp?RecordID=2959

[20] Keeney, R. and Hertel, T. (2008) The Indirect Land Use Impacts of US Biofuels Policies: The Importance of Acreage, Yield and Bilateral Trade Responses. GTAP Working Paper No. 52, Center for Global Trade Analysis, Purdue University, West Lafayette. https://www.gtap.agecon.purdue.edu/resources/res_display.asp?RecordID=2810

[21] Birur, D., Hertel, T. and Tyner, W. (2008) Impact of Biofuel Production on World Agricultural Markets: A Computable General Equilibrium Analysis. GTAP Working Paper No. 53, Center for Global Trade Analysis, Purdue University, West Lafayette. https://www.gtap.agecon.purdue.edu/resources/res_display.asp?RecordID=2413

[22] Taheripour, F., Hertel, T., Tyner, W., Beckman, J. and Birur, D. (2010) Biofuels and Their By-Products: Global Economic and Environmental Implications. Biomass and Bioenergy, 34, 278-289. http://dx.doi.org/10.1016/j.biombioe.2009.10.017

[23] Hertel, W., Golub, A., Jones, A., O’hare, M., Plevin, R. and Kammen, D. (2010) Effects of US Maize Ethanol on Global Land Use and Greenhouse Gas Emissions: Estimating Market-Mediated Responses. Bioscience, 60, 223-231. http://dx.doi.org/10.1525/bio.2010.60.3.8

[24] Tyner, W., Taheripour, F., Zhuang, Q., Birur, D. and Baldos, U. (2011) Land Use Changes and Consequent $\mathrm{CO}_{2}$ Emissions due to US Corn Ethanol Production: A Comprehensive Analysis. Report to Argonne National Laboratory, Department of Agricultural Economics, Purdue University, West Lafayette. https://greet.es.anl.gov/files/8vdox40k

[25] Taheripour, F., Hertel, T. and Tyner, W. (2011) Implications of Biofuels Mandates for the Global Livestock Industry: A Computable General Equilibrium Analysis. Agricultural Economics, 42, 325-342. http://dx.doi.org/10.1111/j.1574-0862.2010.00517.x

[26] Beckman, J., Hertel, T., Taheripour, F. and Tyner, W. (2012) Structural Change in the Bio- 
fuels Era. European Review of Agricultural Economics, 39, 137-156.

http://dx.doi.org/10.1093/erae/jbr041

[27] Taheripour, F., Hertel, T. and Liu, J. (2013) The Role of Irrigation in Determining the Global Land Use Impacts of Biofuels. Energy, Sustainability and Society, 3, 1-18.

http://dx.doi.org/10.1186/2192-0567-3-4

[28] Taheripour, F., Hertel, T. and Liu, J. (2013) Introducing Water by River Basin into the GTAP Model: GTAP-BIO-W. GTAP Working Paper 77, Center for Global Trade Analysis, Purdue University, West Lafayette.

https://www.gtap.agecon.purdue.edu/resources/res_display.asp?RecordID=4304

[29] Liu, J., Hertel, T., Taheripour, F., Zhu, T. and Ringler, C. (2014) Water Scarcity and International Agricultural Trade. Global Environmental Change, 29, 22-31. http://dx.doi.org/10.1016/j.gloenvcha.2014.07.010

[30] Narayanan, G.B., Aguiar, A. and McDougall, R. (Eds.) (2012) Global Trade, Assistance, and Production: The GTAP 8 Data Base. Center for Global Trade Analysis, Purdue University, West Lafayette. https://www.gtap.agecon.purdue.edu/databases/v8/v8_doco.asp

[31] Winchester, N., Ledvina, K., Strzepek, K. and Reilly, J. (2016) The Impact of Water Scarcity on Food, Bioenergy and Deforestation. Report 300, MIT Joint Program on the Science and Policy of Global Change, Massachusetts Institute of Technology, Cambridge, MA, USA.

[32] Clements, B., Coady, D., Fabrizio, S. Gupta, S., Alleyne, T. and Sdralevich, C. (2013) Energy Subsidy Reform: Lessons and Implications. International Monetary Fund, Washington. https://www.imf.org/external/pubs/cat/longres.aspx?sk=40410.0

[33] Jamil, F. (2014) Comparison of Electricity Supply and Tariff Rates in South Asian Countries. Energy Forum, Sri Lanka.

http://www.efsl.lk/reports/electricity_supply_south_asian_countries.pdf

Submit or recommend next manuscript to SCIRP and we will provide best service for you:

Accepting pre-submission inquiries through Email, Facebook, LinkedIn, Twitter, etc.

A wide selection of journals (inclusive of 9 subjects, more than 200 journals)

Providing 24-hour high-quality service

User-friendly online submission system

Fair and swift peer-review system

Efficient typesetting and proofreading procedure

Display of the result of downloads and visits, as well as the number of cited articles

Maximum dissemination of your research work

Submit your manuscript at: http://papersubmission.scirp.org/

Or contact jep@scirp.org 